\title{
Effect of Management Regimes and Elevational Gradient on Soil Microbial Population of Quercus leucotrichophora A. camus Forests in North-West Himalayas, India
}

\author{
Pradeepen Rai $^{1 *}$, Bhupender Gupta ${ }^{1}$, A.K. Gupta ${ }^{2}$, \\ Pempa Lamu Bhutia ${ }^{1}$ and Lalrintluangi Fanai ${ }^{3}$
}

\author{
${ }^{1}$ Department of Silviculture and Agroforestry, Dr.Yashwant Singh Parmar University of \\ Horticulture and Forestry, Nauni-173230, India \\ ${ }^{2}$ Department of Plant Pathology, Dr. Yashwant Singh Parmar University of Horticulture and \\ Forestry, Nauni-173230, India \\ ${ }^{3}$ Department of Forestry, School of Earth Sciences and Natural Resource Management, \\ Mizoram University, Tanhril-796004, India
}

*Corresponding author

\section{Keywords \\ Quercus \\ leucotrichophora, \\ Reserved forest, Protected \\ forest, Unclassified \\ forest, Musterqua forest, \\ Microbial count, \\ Symbiotic \\ Article Info \\ Accepted: \\ 24 August 2018 \\ Available Online: \\ 10 September 2018}

\section{A B S T R A C T}

Forest ecosystems are among the most complex and heterogeneous terrestrial environments. Such heterogeneity is probably due to limited anthropogenic intervention and the perennial status of the primary producers especially forest trees. Soil microorganisms (e.g., bacteria, fungi and actinomycetes etc.) play a vital role in biogeochemical cycling in forest soils maintaining life on earth, fixing gases and breaking down of dead plant and animal matter into simpler substances that are used at the beginning of the food chain. Study on such organisms is crucial in understanding their roles and functions in forest ecosystem. Therefore, four differently managed Quercus leucotrichophora forests types viz. Reserved Forest (RF), Protected Forest (PF), Unclassified Forest (UF) and Musterqua Forest (MF)) at Rajgarh Forest Division in Sirmour district of Himachal Pradesh were investigated to explore the effect of management regimes and elevational gradient on soil microbial population. In each forest types along the elevation gradient, composite soil samples were collected from tree rhizosphere zone and also from between the tree spaces up to the depth of $0-30 \mathrm{~cm}$ to study microbial population and physico-chemical properties. The present study results revealed that microbial population in differently managed $Q$. leucotrichophora forests decreased significantly in the order Reserved Forest > Protected Forest > Unclassified Forest > Musterqua Forest. Bacterial and actinomycetes population count showed positive increasing trend along the elevation gradient while fungi exhibited reverse trend. Furthermore, correlation study suggested that microbial population showed positive relationship with Electrical conductivity (EC) and Soil organic Carbon (SOC) while negative response with soil $\mathrm{pH}$ and Bulk Density (BD). Thus, these Quercus forests sheltered substantial soil microbes which varied significantly according to the management regimes and elevation gradient exhibiting great influence on its population. 


\section{Introduction}

Forest soil is known to harbour soil microorganisms and provide rich habitat for their growth. Soil microorganisms are essential components of the biotic community in natural forests, responsible for the breakdown of organic materials, mobilization of nutrients, maintenance of soil-plant quality and ecosystem biogeochemistry (Hackl et al., 2004). Bacteria, fungi and actinomycetes are the major organisms inhabiting the soil fraction and play an important role in both natural and agro-ecosystems. Soil bacteria are one of the important biotic components that influence decomposition and nutrient mineralization in the terrestrial ecosystems. Besides, soil fungi and actinomycetes also play a crucial role in the decomposition of plant structural polymers such as cellulose, hemicelluloses and lignin, thereby contributing to the maintenance of the global nutrient cycle. Microbial diversity and population studies are important in order to understand the microbial ecology in soil and other ecosystems (Atlas, 1984). Therefore, much more needs to be done to understand the role of microorganisms and inventory of their diversity and population to find ways to exploit them beneficially (Bardgett, 2005).Great deal of scientific attention has been received to understand the diversity and population of plants and animals in forests and agro-ecosystems, whereas, such studies for soil microorganisms is often ignored. Few studies were conducted to investigate elevation trends in microbial distribution (Bryant et al., 2008; Fierer et al., 2011) showing a broad range of richness/ diversity patterns in relation to elevation. Study of soil samples from varying elevations on a broad geographical scale across the Americas (Lauber et al., 2009) suggested no trend with elevation; whereas a more localized systematic study in mountains of the SW USA suggested a decline in bacterial richness/ diversity towards higher elevations (Bryant et al., 2008). Both studies provide insight on the relationship between elevation and microbial richness/diversity. Margesin et al., (2009) reported an increasing trend for Gram negative bacterial population along elevation gradient. While decreasing diversity of soil fungi with increasing altitude had been reported earlier (Schinner and Gstraunthaler, 1981). Furthermore, a negative correlation between bacterial population and altitude was reported by Ma et al., (2004) in the cold temperate Kalasi Lake and by Giri et al., (2007) in a tropical dry deciduous forest. Soil microorganisms are also known to influence the soil physical and chemical properties. Evaluating soil physico-chemical characteristics provide useful information on soil microbial activity. To see the microbial activities, it is necessary to study the interrelationship between the physical and chemical properties of soil (Meliani et al., 2012). Although some reports on the relationship between soil microbial communities and soil properties are available, relatively less attention has been paid on the Q. leucotrichophora forest stands of Western Himalaya. Therefore, the present investigation was conducted with an aim to assess the impact of forest management regimes, elevation gradient and soil physico-chemical properties on the dynamics of soil microbial population.

\section{Materials and Methods}

\section{Study area}

The study was conducted in Rajgarh Forest Division of Himachal Pradesh which lies between longitude $77^{\circ} 1$ ' 5 " to $77^{\circ} 26^{\prime} 13$ " East and latitude $30^{\circ} 38^{\prime} 40^{\prime \prime}$ to $31^{\circ} 1^{\prime} 14^{\prime \prime}$ "North in the northwest Himalaya, India (Fig. 1). The area is mostly mountainous with sub-tropical to alpine climate and receives average annual rainfall of $1500 \mathrm{~mm}$ where $60 \%$ i.e. $900 \mathrm{~mm}$ 
of precipitation is received during monsoon months starting by end of June and last till mid-September. Though the slopes are quite steep, but still have deep clayey loam soil, quite rich in humus under dense oak. Quercus leucotrichophora forests in this Forest Division differ in the extent of biotic interference and are managed under different regimes such as Reserved Forest (RF), Protected Forest (PF), Unclassified Forest (UF) and Musterqua Forest (MF). They have their respective elevation range of existence as1680-2322 m, 1400-2000 m, 1500-2000 m and 1200-1950 m, respectively. To study different physico-chemical and biological properties of soil, each of these differently managed $Q$. leucotrichophora forest was delineated into three elevations zones i.e., < $1650 \mathrm{~m}\left(\mathrm{E}_{1}\right), 1651$ to $1900 \mathrm{~m}\left(\mathrm{E}_{2}\right)$ and $>1900$ $\mathrm{m}\left(\mathrm{E}_{3}\right)$ elevation zones.

\section{Soil sampling}

Four replicated sample plots of size $31.62 \mathrm{~m} \times$ $31.62 \mathrm{~m}$ (0.1 ha) were laid out randomly with a minimum consecutive distance of $500 \mathrm{~m}$ in each of the differently managed $Q$. leucotrichophora forests at each elevation where soil samples were collected from within the sample plot up to a depth of 0-30 cm after removing surface litter and debris. Soil samples were collected from the rhizospheric zone by visiting different sized ban oak trees within the plot using soil auger and then those samples so collected was composited. A total of 48 composite soil samples were obtained from the entire experimental sites (4 forest types $\mathrm{x} 4$ replicated inventory plots $\mathrm{x} 3$ elevations). Each soil sample was sieved through a $2 \mathrm{~mm}$ mesh screen, carefully separated from root fragments and stones and divided into two parts. One part were sealed in container and kept in refrigerator at $4{ }^{\circ} \mathrm{C}$ in the field moisture condition for microbial count analysis and the other part was air dried to study physico-chemical characteristics. The microbial population was estimated within 24 hrs of sampling.

\section{Soil analysis}

The microbial population was studied through serial dilution and plating techniques (Wollum, 1982). Soil samples were serially diluted with distilled water up to $10^{-7}, 10^{-5}$ and $10^{-3}$ dilution for bacteria, actinomycetes and fungi respectively. Media were prepared according to the composition and sterilized in autoclave. $100 \mu \mathrm{l}$ of aliquot was poured in plates having selective media (Nutrient Agar for bacteria; Rose Bengal Agar for fungi; Ken Knights and Munaier's Agar for actinomycetes). For actinomycetes, streptomycin and cycloheximide were added to inhibit the growth of bacteria and fungi at a final concentration following Yang and Yang (2001). The petri-plates were incubated at optimum temperature $\left(28 \pm 1{ }^{\circ} \mathrm{C}\right.$ for bacteria; $30 \pm 1{ }^{\circ} \mathrm{C}$ for fungi and actinomycetes) in triplicates and appeared microbial colonies were counted ( 7 days for actinomycetes, 3 days for bacteria and 5 days for fungi;) after incubation and expressed as total culturable colony forming units (CFUs)/g dry weight of soil sample.

Bulk density of soil was determined by Coretube method given by (USDA, 1954). The $\mathrm{pH}$ and EC of the sampled soils were measured by using soil digital $\mathrm{pH}$ meter and EC meter respectively following standard techniques given by Jackson (1973) in 1: 5 soil-water suspension. Soil organic carbon was determined by following Walkley and Black (1934) method.

\section{Data analysis}

Data analysis was carried out using JMP 10SAS software package. Data for different parameters was subjected to analysis of variance (ANOVA) and means were 
compared by Tukey's test $(\mathrm{P}<0.05)$. Correlation analysis was done to compare strength of relationship between different parameters as function of differently managed forests and elevations by using SPSS version 16.0 .

\section{Results and Discussion}

\section{Soil physico-chemical properties}

Soil $\mathrm{pH}$ plays an important role on microbial activity in soil, decomposition of organic matter and release of plant nutrients and also acts as important factors in many soil improvement processes. In the present study, mean $\mathrm{pH}$ of soil varied significantly $(p<0.05)$ among differently managed $Q$. leucotrichophora forests and non-significantly $(p<0.05)$ along elevation (Table 1). The mean $\mathrm{pH}$ of soil varied from 5.63 (Reserved Forest) to 6.83 (Musterqua Forest). Among differently managed $Q$. leucotrichophora forests the following decreasing trend was observed: Musterqua Forest (6.83) > Unclassified Forest (6.05) > Protected Forest (5.81) > Reserved Forest (5.63). Electrical conductivity (EC) of soils is generally used to determine soil salinity and serve as a measure of soluble nutrients in the soil (Kumar et al., 2012). Many authors had reported relation that exists between soil EC and the variations in production of vegetational systems. The soils in present study was low in soluble salt concentration varied significantly amongst differently managed Forest: Reserved Forest $\left(0.24 \mathrm{dS} / \mathrm{m}^{2}\right)>$ Protected Forest $\left(0.20 \mathrm{dS} / \mathrm{m}^{2}\right)>$ Unclassified Forest $\left(0.16 \mathrm{dS} / \mathrm{m}^{2}\right)>$ Musterqua Forest $\left(0.14 \mathrm{dS} / \mathrm{m}^{2}\right)$ but did not vary along elevation at $(\mathrm{p}<0.05)$. The interaction of forest types and elevations effected soil electrical conductivity significantly. Organic carbon in soil is generally associated with quantity of organic matter addition and the rate of organic matter decomposition where the rate of decomposition depends upon several climatic variables (rainfall and temperatures), edaphic (soil moisture, soil temperature), biotic (microbial activities) and topographic factors (aspect, exposure and slope). Soil organic carbon (SOC) among differently managed forest varied significantly $(p<0.05)$ in the range of $2.90 \%$ (Musterqua Forest) to $3.62 \%$ (Reserved Forest) (Table 1). There was nonsignificant linear relationship between SOC and elevation with non-significant highest SOC at elevation $\mathrm{E}_{3}(3.47 \%)$ and lowest SOC at elevation $\mathrm{E}_{1}(3.29 \%)$. Bulk density is a measure of compactness which is associated with water holding capacity of soil and is widely used for determining sol organic carbon. Our results indicated that both differently managed forest and elevation had significant effect on bulk density of soil. It varied from $\left(1.36 \mathrm{~g} \mathrm{~cm}^{-3}\right)$ in Reserved Forest to $\left(1.48 \mathrm{~g} \mathrm{~cm}^{-3}\right)$ in Musterqua Forest among differently managed forest $(\mathrm{p}<0.05)$ and $\left(1.37 \mathrm{~g} \mathrm{~cm}^{-3}\right)$ in elevation $\left(\mathrm{E}_{3}\right)$ to $\left(1.48 \mathrm{~g} \mathrm{~cm}^{-3}\right)$ in elevation $\left(\mathrm{E}_{1}\right)$ along elevation gradient $(\mathrm{p}<0.05)$.

The lowest $\mathrm{pH}$ in Reserved Forest and Protected Forest can be associated to higher litter production, its accumulation and decay releasing organic acids as argued by De Hann (1977); Tornquist et al., (1999); Gairola et al., (2012). Beside them, increased $\mathrm{CO}_{2}$ levels through root respiration and microbial respiration are also responsible for decrease in soil pH (Jorgensen and Wells, 1973; De Jong et al., 1974; Edward, 1975; Yao et al., 2010). Low $\mathrm{pH}$ has also been observed in undisturbed natural forests in comparison to disturbed ecosystems (Adams and Sidle, 1987; Robertson and Vitousek, 1981). The higher $\mathrm{pH}$ of soil in Masterqua Forest compared to the other managed forest can be related to low amount of organic matter (organic carbon) in the soil due to higher biotic interference. Mean soil $\mathrm{pH}$ did not follow any regular trend with elevation. The values of $\mathrm{pH}$ in present study are similar to those values of $\mathrm{pH}$ recorded by 
Jina et al., (2008); Kharkwal (2002); Usman et al., (2000); Srivastava et al., (2005); Sharma et al., (2010); Semwal (2006); Kumar et al., (2004); Pande et al., (2004); Gairola et al., (2012). Lowest EC in MF could have resulted from greater leaching of salts due to sparse cover of vegetation. Disturbed forest have more leaching due less evaporative demand of vegetation and less canopy interception of rainfall than the undisturbed forested areas (Reynolds et al., 1988; Blank and Fosberg, 1989; Naidu et al., 1996; Abbasi et al., 2010). Maximum SOC in Reserved Forest may be attributed to higher input of litter due to nonexistence of biotic interference which results in the maximum concentration of organic matter thereby carbon in the soil. The lower SOC in the soil of Musterqua Forest reflects the low litter deposition because of high biotic disturbance and perhaps enhanced decomposition of litter due to continuous exposure (Arunachalam et al., 1999; Murty et al., 2002; Pandey et al., 2007). In the present study, no relationship between altitude and soil carbon was observed, which may be due to different composition of understory vegetation along the altitudinal gradient and their differential decomposition rates. Highest bulk density in MF was due to compaction of top soil by grazing animal (Taboada and Lavado, 1993). In addition, low soil organic carbon can be further attribute to high bulk density (Murty et al., 2002; Pandey et al., 2007; Dorji, 2014). However, RF soil recorded lowest bulk density which can be related to higher organic carbon, proliferation of rhizosphere, enhanced microbial activities, and root exudation below ground which helps to bind soil particles into large aggregates and thereby loosen the soil and decrease its bulk density (Nair, 1984; Young, 1991; Fisher, 1995; Ramesh et al., 2013). In the present study, bulk density decreased along elevation which can be related to increasing soil organic matter. Leifeld et al., 2005 and Morisada et al., 2004 contended that the bulk density depends on several factors such as compaction, consolidation and amount of SOC present in the soil but it is highly correlated to the organic carbon content. Soils with high organic matter accumulation are high in pore space regardless of the amount of soil particles in the soil and thus results in lower bulk density while soils with higher bulk density have lower OM resulting in lower percent pores space. Sanjay et al., (2010) also reported lower bulk density at top altitudes and argued that it is a good indicator of soils that has coarser structure of organic matter which enriches the spaces by soil organic carbon.

\section{Soil microflora count}

In the present study among different managed Q. leucotrichophora forests, bacterial population showed decreasing trend of: Reserved Forest (30.77) > Protected Forest (21.38) > Unclassified Forest (19.80) > Musterqua Forest (18.65) (Table 2). However, its population decreased with an increase in elevation gradient $E_{1}(32.94)>E_{2}(21.05)>E_{3}$ (13.96). Similar trend in actinomycetes population was also recorded as Reserved Forest (24.33) > Protected Forest (16.50) > Unclassified Forest (16.17) > Musterqua Forest (16.17). Significant variation was observed in its population along the elevation which decreased with increase in elevation as depicted: $\mathrm{E}_{1}(23.75)>\mathrm{E}_{2}(17.75)>\mathrm{E}_{3}$ (13.37). Fungal population with regard to different managed forests was found to be significant and it tend to decrease with decrease in degree of protection as Reserved Forest (29.83) > Protected Forest (19.17) > Unclassified Forest (15.67) > Musterqua Forest (13.17) while it showed an interesting increasing trends with the increase in elevational gradient i.e. $\mathrm{E}_{1}$ (12.88) $>\mathrm{E}_{2}$ (17.75) $>\mathrm{E}_{3}(27.75)$ which is totally opposite unlike the trend shown by the other two microbial population. Overall, we can conclude that bacteria, actinomycetes and fungal count in soil of different managed $Q$. 
leucotrichophora forests decreased in the order: Reserved Forest > Protected Forest > Unclassified Forest > Musterqua Forest revealing that Reserved Forest's soil health is better and nurture good microbial growth and distribution as compared to other three forests. Bacterial and actinomycetes count of soil in $Q$. leucotrichophora forest decreased significantly along the elevation whereas mean fungal count increased significantly with an increase in elevation.

Higher bacterial, actinomycetes and fungal count in Reserved Forest may be due to the higher pore space and organic material added to the soil through leaf litter which serves as a source of energy for microbial population. The decrease in bacterial count with an increase in elevation in this present study is in accordance with Pandey and Palani (2007). Bryant et al., (2008) also reported that bacterial taxon richness and phylogenetic diversity decreased monotonically from the lowest to the highest elevations. Comparable range of bacterial colonies ranging from $1.8 \times 10^{3}$ to $3.2 \times 10^{8}$ (cfu/g of dry soil) were reported by Lyngwi $e t$ al., (2013) in tropical forest of Eastern Himalaya.

They further reported that CFU counts of bacteria decreased with increasing altitude, as highest CFU counts were recorded at lower altitudes and lowest CFU counts were recorded at higher altitudes. Laldinthar and Dkhar (2015) reported positive correlation of bacterial population with organic carbon and total nitrogen in forest stands of Meghalaya and further stressed that these two constitute the major driving factors of bacterial population. Pandey and Palni (2007) reported that coniferous species of subtropical and temperate locations viz., Cedrus, Pinus and Taxus support larger population of microbial population in the rhizosphere. Higher microorganisms and its activity in forest and grassland are due to plant residues, plant roots, and more organic matter (Yousefifard et al., 2007).

As elevation increases, the soil is under cold and harsh conditions and the tree root exudates tend to become more acidic, and exert a negative influence on the microbial population as reported in forests of temperate and sub alpines areas which might be the cause of decrease in bacteria and actinomycetes count as observed in the present studies. Lejon et al., (2005); Snajdr et al., (2008) found that Oak forest harboured highest microbial population. Zhang et al., (2013) concluded that soil $\mathrm{pH}$ and $\mathrm{C} / \mathrm{N}$ ratio were the most important drivers for microbial community structure.

Soil physico-chemical properties as of Reserved Forest support ample growth and survival of soil biota. Critter et al., (2002) evaluated both groups of microorganisms (bacteria and fungi) in soil samples quantitatively using agar plate counts and found that amendment with different organic materials affected significantly their quantity.

The high values for soil microbial biomass and enzymes activities found under forest vegetation may be attributed to the relatively high quantity and quality of plant litter supporting a larger microbial biomass and activity due to the availability of above- and belowground carbon sources (Nsabimana et al., 2004). Our results corroborate with others studies (Templer et al., 2005; Silva et al., 2012) in tropical systems where the inputs of plant litter and soil nutrients increased the soil microbial biomass and activity. Higher fungal count in the Reserved Forest may be due to low $\mathrm{pH}$ and higher organic matter content, possibly due to root biomass incorporation and huge amount of leaf litter accumulation. These results are in accordance with the findings of Jalali et al., (1989) and Qin et al., (2006). 
Fig.1 Map of the study area

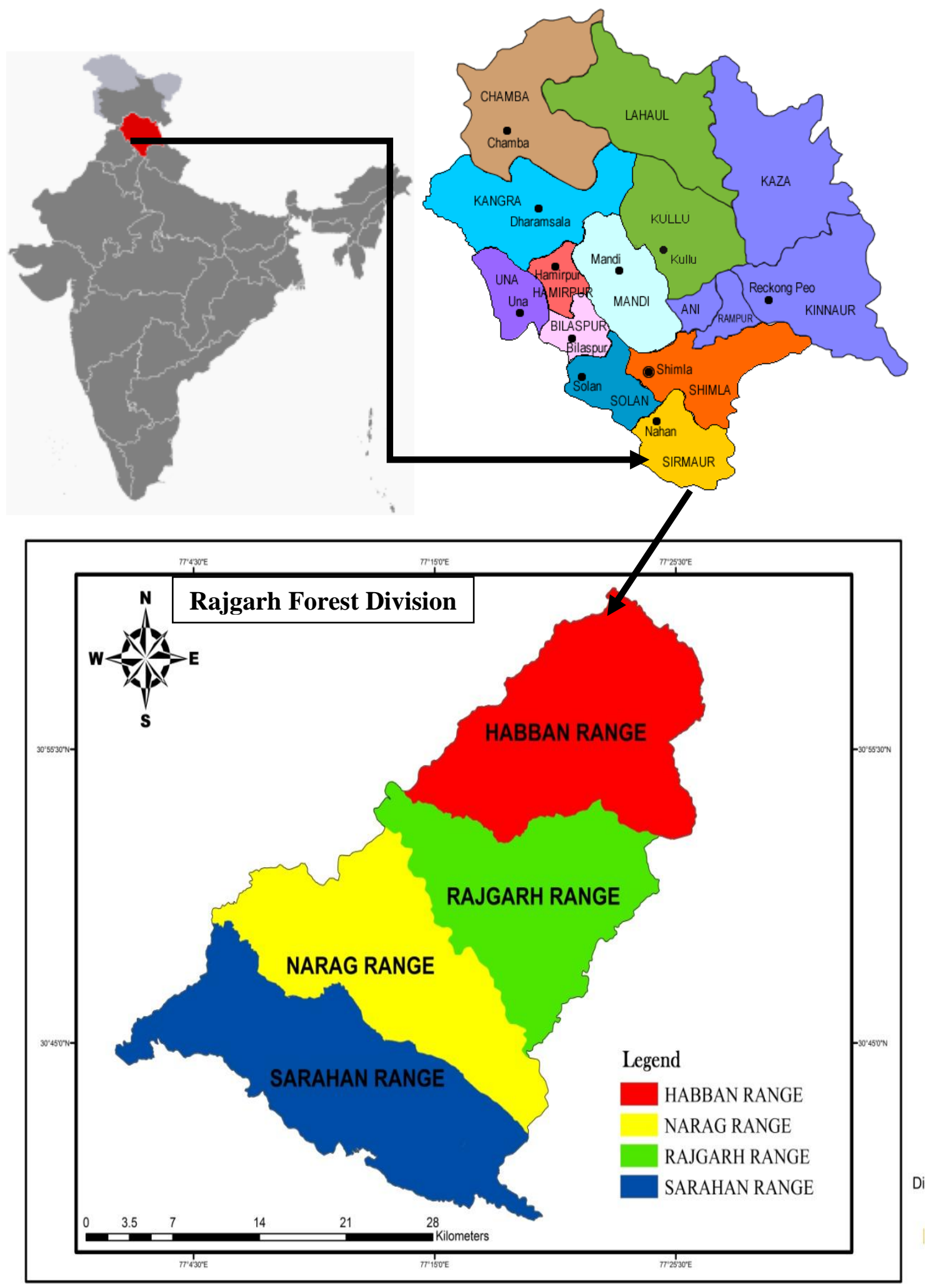


Table.1 Physico-chemical properties of soil at 0-30 $\mathrm{cm}$ depth under differently managed

$Q$. leucotrichophora forests along the elevation

\begin{tabular}{|c|c|c|c|c|c|c|c|c|c|c|c|c|c|c|c|c|}
\hline \multirow[t]{3}{*}{$\begin{array}{l}\text { Forest } \\
\text { (F) }\end{array}$} & \multicolumn{4}{|c|}{ pH of soil } & \multicolumn{4}{|c|}{$\begin{array}{c}\text { EC of soil } \\
\left(\mathrm{dS} / \mathrm{m}^{2}\right)\end{array}$} & \multicolumn{4}{|c|}{$\begin{array}{c}\text { S O C } \\
(\%)\end{array}$} & \multicolumn{4}{|c|}{$\begin{array}{l}\text { Bulk density of soil } \\
\left(\mathrm{g} \mathrm{cm}^{-3}\right)\end{array}$} \\
\hline & \multicolumn{4}{|c|}{ Elevation (E) } & \multicolumn{4}{|c|}{ Elevation (E) } & \multicolumn{4}{|c|}{ Elevation (E) } & \multicolumn{4}{|c|}{ Elevation (E) } \\
\hline & $\mathbf{E}_{1}^{*}$ & $\mathbf{E}_{2}^{*}$ & $\mathbf{E}_{3}^{*}$ & $\begin{array}{l}\text { Mea } \\
\text { n (F) }\end{array}$ & $\mathbf{E}_{1}^{*}$ & $\mathbf{E}_{2}^{*}$ & $\mathbf{E}_{3}^{*}$ & $\begin{array}{c}\text { Mean } \\
(\mathbf{F})\end{array}$ & $\mathbf{E}_{1}^{*}$ & $\mathbf{E}_{2}^{*}$ & $\mathbf{E}_{3}^{*}$ & Mean & $\mathbf{E}_{1}^{*}$ & $\mathbf{E}_{2}^{*}$ & $\mathbf{E}_{3}{ }^{*}$ & Mean \\
\hline Reserved Forest & $5.68 d$ & $5.55 \mathrm{~d}$ & $5.66 d$ & $5.63 c$ & 0.26 & 0.22 & 0.25 & $0.24 \mathrm{a}$ & 3.50 & 3.39 & 3.97 & $3.62 \mathrm{a}$ & $\begin{array}{c}1.40 \\
\text { bc }\end{array}$ & $\begin{array}{c}1.35 \\
\mathbf{c}\end{array}$ & $\begin{array}{c}1.34 \\
\text { c }\end{array}$ & $1.36 \mathrm{c}$ \\
\hline Protected Forest & $6.01 \mathrm{bcd}$ & $5.71 d$ & $5.71 d$ & $\begin{array}{c}5.81 b \\
\mathrm{c}\end{array}$ & 0.21 & 0.18 & 0.20 & $0.20 \mathrm{~b}$ & 3.48 & 3.67 & 3.60 & $3.59 \mathrm{a}$ & $\begin{array}{c}1.43 \\
\text { bc }\end{array}$ & $\begin{array}{c}1.42 \\
\text { bc }\end{array}$ & $\begin{array}{c}1.33 \\
\text { c }\end{array}$ & $1.39 \mathrm{bc}$ \\
\hline $\begin{array}{l}\text { Unclassified } \\
\text { Forest } \\
\end{array}$ & $5.78 \mathrm{~cd}$ & $\begin{array}{c}5.91 \mathrm{c} \\
\mathbf{d}\end{array}$ & $\begin{array}{c}6.45 \mathbf{a} \\
\mathbf{b c}\end{array}$ & $6.05 b$ & 0.19 & 0.14 & 0.16 & $0.16 \mathrm{c}$ & 3.31 & 3.52 & 3.46 & $\begin{array}{c}3.43 \\
\text { ab }\end{array}$ & $\begin{array}{c}1.49 \\
\mathbf{a b}\end{array}$ & $\begin{array}{c}1.43 \\
\text { bc }\end{array}$ & $\begin{array}{c}1.41 \\
\text { bc }\end{array}$ & $1.44 \mathbf{a b}$ \\
\hline $\begin{array}{l}\text { Musterqua } \\
\text { Forest }\end{array}$ & $6.91 \mathbf{a}$ & $6.96 \mathbf{a}$ & $\begin{array}{c}6.61 \mathbf{a} \\
\mathbf{b}\end{array}$ & $6.83 a$ & 0.15 & 0.13 & 0.14 & $0.14 \mathrm{~d}$ & 2.85 & 2.97 & 2.87 & $2.90 \mathrm{~b}$ & $\begin{array}{c}1.61 \\
\mathbf{a}\end{array}$ & $\begin{array}{c}1.43 \\
\text { bc }\end{array}$ & $\begin{array}{c}1.41 \\
\text { bc }\end{array}$ & $1.48 \mathrm{a}$ \\
\hline \multirow[t]{2}{*}{ Mean (E) } & 6.10 & 6.03 & 6.11 & & 0.20 & 0.17 & 0.19 & & 3.29 & 3.39 & 3.47 & & $\begin{array}{c}1.48 \\
a\end{array}$ & $\begin{array}{c}1.41 \\
\text { ab }\end{array}$ & $\begin{array}{c}1.37 \\
b\end{array}$ & \\
\hline & \multicolumn{4}{|c|}{$\begin{array}{l}\text {-Mean Mean }(\mathrm{F}) \text { and Interaction }(\mathrm{F} \mathrm{x} \\
\mathrm{E}) \text { were significant }[\text { Mean }(\mathrm{F}) \text { : Adj } \\
\mathrm{R}^{2}=0.68, \mathrm{~F} \text { ratio }=34.81, \mathrm{P} \\
<0.0001, \mathrm{q}=2.67 ; \text { Interaction }(\mathrm{F} \mathrm{x} \\
\mathrm{E}): \mathrm{F} \text { ratio }=3.47, \mathrm{P}=0.0083, \mathrm{q}= \\
3.49] \\
\text { Adj } \mathrm{R}^{2} \text { Mean }(\mathrm{E}) \text { was non- } \\
\text { significant [ } \mathrm{F} \text { ratio }=0.08, \mathrm{P} \\
>0.9201] \\
0.61, \mathrm{~F} \text { Different successive letters } \\
\text { suffixing the numbers in the } \\
\text { columns for 'Mean }(\mathrm{F}) \text { ' and } \\
\text { columns and rows for 'Interaction } \mathrm{F} \\
\mathrm{x} \text { E' denote significant difference }\end{array}$} & \multicolumn{4}{|c|}{$\begin{array}{l}\text { Mean }(\mathrm{F}) \text { was significant } \\
{\left[\text { Mean }(\mathrm{F}): \text { Adj } \mathrm{R}^{2}=0.85, \mathrm{~F}\right.} \\
\text { ratio }=87.74, \mathrm{P}<0.0001, \mathrm{q}= \\
2.67] \\
\text { Mean }(\mathrm{E}) \text { and Interaction ( } \mathrm{F} x \\
\text { E) were non-significant } \mathrm{Mean} \\
(\mathrm{E}) ; \mathrm{F} \text { ratio }=0.08, \mathrm{P}=0.0791 \text {; } \\
\text { Interaction (F x E): F ratio = } \\
2.20, \mathrm{P}=0.0658] \\
\text { Different successive letters } \\
\text { suffixing the numbers in the } \\
\text { columns for 'Mean }(\mathrm{F}) \text { ' denote } \\
\text { significant difference }\end{array}$} & \multicolumn{4}{|c|}{$\begin{array}{l}\text { Mean }(\mathrm{F}) \text { was significant } \\
{\left[\text { Mean }(\mathrm{F}) \text { : Adj } \mathrm{R}^{2}=0.20, \mathrm{~F}\right.} \\
\text { ratio }=5.03, \mathrm{P}=0.0044, \mathrm{q} \\
=2.67 ; \\
\text { Mean }(\mathrm{E}) \text { and Interaction }(\mathrm{F} \\
\text { x E) were non-significant } \\
{[\text { Mean }(\mathrm{E}) ; \mathrm{F} \text { ratio }=0.04, \mathrm{P}} \\
=6632 ; \text { Interaction }(\mathrm{F} \times \mathrm{E}) \text { : } \\
\mathrm{F} \text { ratio }=0.38, \mathrm{P}=0.8895] \\
\text { Different successive letters } \\
\text { suffixing the numbers in the } \\
\text { columns for 'Mean }(\mathrm{F}) \text { ' } \\
\text { denote significant } \\
\text { difference }\end{array}$} & \multicolumn{4}{|c|}{$\begin{array}{l}\text { Mean }(\mathrm{F}), \text { Mean }(\mathrm{E}) \text { and } \\
\text { Interaction }(\mathrm{F} \times \mathrm{E}) \text { were } \\
\text { significant }[\text { Mean }(\mathrm{F}) \text { : Adj } \\
\mathrm{R}^{2}=0.26, \mathrm{~F} \text { ratio }=6.50, \mathrm{P}= \\
0010, \mathrm{q}=2.67 ; \text { Mean }(\mathrm{E}) \text { : } \\
\mathrm{Adj}^{2}=0.30, \mathrm{~F} \text { ratio }= \\
10.88, \mathrm{P}=0.0001, \mathrm{q}=2.42 ; \\
\text { Interaction }(\mathrm{F} \times \mathrm{E}): \mathrm{F} \text { ratio }= \\
2.86, \mathrm{P}=0.0218, \mathrm{q}=3.49] \\
\text { Different successive letters } \\
\text { suffixing the numbers in the } \\
\text { columns for 'Mean }(\mathrm{F}) \text { ', } \\
\text { rows for 'Mean }(\mathrm{E}) \text { ' and } \\
\text { rows and columns for } \\
\text { 'Interaction F x E' denote } \\
\text { significant difference }\end{array}$} \\
\hline
\end{tabular}

$* \mathrm{E}_{1}=<1650 \mathrm{~m}, \mathrm{E}_{2}=1651-1900$ and $\mathrm{E}_{3}=>1900 \mathrm{~m}$ 
Table.2 Microbial population of soil at 0-30 cm depth under differently managed Q. leucotrichophora forests along the elevation

\begin{tabular}{|c|c|c|c|c|c|c|c|c|c|c|c|c|}
\hline & \multicolumn{4}{|c|}{ Bacteria (CFU/g) x 10 } & \multicolumn{4}{|c|}{ Actinomycetes (CFU/g) x $10^{5}$} & \multicolumn{4}{|c|}{ Fungal count $\times 10^{3}$} \\
\hline & \multicolumn{3}{|c|}{ Elevation $(\mathbf{E})$} & \multirow[b]{2}{*}{$\begin{array}{l}\text { Mean } \\
(\mathrm{F})\end{array}$} & \multicolumn{3}{|c|}{ Elevation $(\mathrm{E})$} & \multirow[b]{2}{*}{$\begin{array}{l}\text { Mean } \\
\text { (F) }\end{array}$} & \multicolumn{3}{|c|}{ Elevation $(\mathrm{E})$} & \multirow[b]{2}{*}{$\begin{array}{l}\text { Mean } \\
\text { (F) }\end{array}$} \\
\hline $\begin{array}{c}\text { Forest } \\
\text { Types } \\
\text { (F) } \\
\end{array}$ & $\mathbf{E}_{1}{ }^{*}$ & $\mathbf{E}_{2}{ }^{*}$ & $\mathbf{E}_{3}{ }^{*}$ & & $\mathbf{E}_{1}^{*}$ & $\mathbf{E}_{2}{ }^{*}$ & $\mathbf{E}_{3}{ }^{*}$ & & $\mathbf{E}_{1}^{*}$ & $\mathbf{E}_{2}^{*}$ & $\mathbf{E}_{3}{ }^{*}$ & \\
\hline $\begin{array}{l}\text { Reserve } \\
\text { Forest }\end{array}$ & $53.50 \mathrm{a}$ & $\begin{array}{c}24.45 \\
\mathrm{c}\end{array}$ & $\begin{array}{l}14.35 \\
\mathrm{fg}\end{array}$ & $30.77 \mathbf{a}$ & 31.50 & 25.50 & 16.00 & $\begin{array}{c}24.33 \\
\text { a }\end{array}$ & $20.50 \mathrm{bc}$ & $23.00 \mathrm{bc}$ & $46.00 \mathbf{a}$ & $\begin{array}{c}29.83 \\
\mathrm{a}\end{array}$ \\
\hline $\begin{array}{l}\text { Protected } \\
\text { Forest } \\
\end{array}$ & $27.80 \mathrm{~b}$ & $\begin{array}{c}23.95 \\
c\end{array}$ & $12.40 \mathrm{~g}$ & 21.38ab & 21.50 & 15.00 & 13.00 & $\begin{array}{c}16.50 \\
b\end{array}$ & $14.00 \mathrm{def}$ & $19.50 \mathrm{bcd}$ & $24.00 \mathrm{~b}$ & $\begin{array}{c}19.17 \\
\text { b }\end{array}$ \\
\hline $\begin{array}{l}\text { Unclassified } \\
\text { Forest }\end{array}$ & $24.25 \mathrm{c}$ & $\begin{array}{c}18.85 \\
d\end{array}$ & $16.30 \mathrm{ef}$ & $19.80 \mathrm{~b}$ & 22.00 & 14.00 & 12.50 & $\begin{array}{c}16.17 \\
b\end{array}$ & $85.00 \mathbf{f}$ & $17.00 \mathrm{cde}$ & $21.50 \mathrm{bc}$ & $\begin{array}{c}15.67 \\
b\end{array}$ \\
\hline $\begin{array}{l}\text { Musterqua } \\
\text { Forest }\end{array}$ & $26.20 \mathrm{bc}$ & $\begin{array}{c}16.95 \\
\text { de }\end{array}$ & $12.80 \mathrm{~g}$ & $18.65 \mathrm{~b}$ & 20.00 & 16.50 & 12.00 & $\begin{array}{c}16.17 \\
b\end{array}$ & $85.00 \mathbf{f}$ & $11.50 \mathrm{ef}$ & $19.50 \mathrm{bcd}$ & $\begin{array}{c}13.17 \\
\text { b }\end{array}$ \\
\hline \multirow[t]{2}{*}{ Mean (E) } & 32.94 a & $\begin{array}{c}21.05 \\
b\end{array}$ & $13.96 \mathrm{c}$ & & $\begin{array}{c}23.75 \\
a\end{array}$ & $\begin{array}{c}17.75 \\
b\end{array}$ & $13.37 b$ & & $12.88 \mathrm{~b}$ & $17.75 \mathrm{~b}$ & 27.75a & \\
\hline & \multicolumn{4}{|c|}{$\begin{array}{l}\text { Mean }(F), \text { Mean }(E) \text { and Interaction } \\
(F \times E) \text { were significant }[\text { Mean }(F) \text { : } \\
\text { Adj } R^{2}=0.15, F \text { ratio }=3.69, P= \\
0.0186, \mathrm{P}=2.67 ; \text { Mean }(E): \text { Adj } \mathrm{R}^{2}= \\
0.52, \mathrm{~F} \text { ratio }=26.25, \mathrm{P}<0.0001, \mathrm{q}= \\
2.42 ; \text { Interaction }(\mathrm{F} \times \mathrm{E}): \mathrm{F} \text { ratio }= \\
223.41, \mathrm{P}<0.0001, \mathrm{q}=3.49] \\
\text { Different successive letters suffixing } \\
\text { the numbers in the columns for 'Mean } \\
(\mathrm{F}) \text { ', rows for 'Mean }(\mathrm{E}) \text { ' and } \\
\text { columns and rows for interaction } \\
\text { denote significant difference }\end{array}$} & \multicolumn{4}{|c|}{ 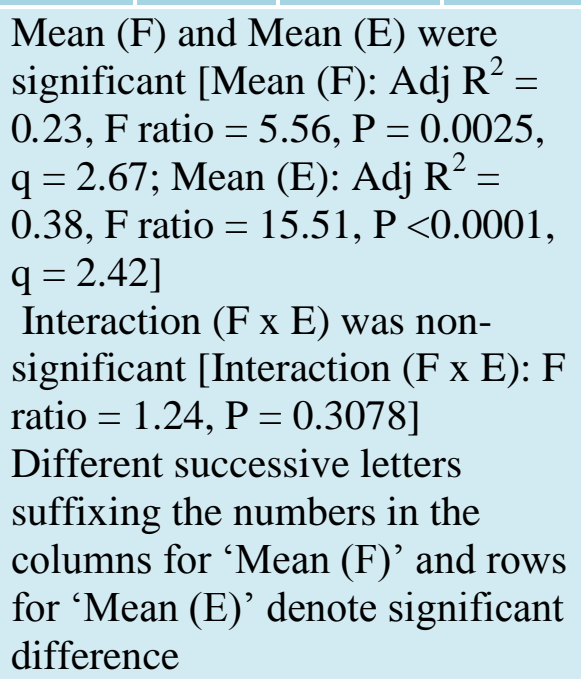 } & \multicolumn{4}{|c|}{$\begin{array}{l}\text { Mean }(F), \text { Mean }(E) \text { and Interaction }(F x \\
E) \text { were significant }\left[\text { Mean }(F) \text { : Adj } R^{2}=\right. \\
0.39, F \text { ratio }=9.38, P<0.0001, q=2.67 ; \\
\text { Mean }(E) \text { : Adj } R^{2}=0.34, F \text { ratio }=13.21 \text {, } \\
P<0.0001, q=2.42 ; \text { Interaction }(F x E): F \\
\text { ratio }=5.10, P=0.0007, q=3.49] \\
\text { Different successive letters suffixing the } \\
\text { numbers in the columns for 'Mean }(F) \text { ', } \\
\text { rows for 'Mean }(E) \text { ' and columns and } \\
\text { rows for interaction denote significant } \\
\text { difference }\end{array}$} \\
\hline
\end{tabular}


Table.3 Correlation coefficient between soil physico-chemical properties and soil microbes of Quercus leucotrichophora forest

\begin{tabular}{|c|c|c|c|c|}
\hline & $\mathbf{p H}$ & $\mathbf{E C}$ & $\mathbf{S O C}$ & $\mathbf{B D}$ \\
\hline $\mathbf{p H}$ & 1 & & & \\
\hline $\mathbf{E C}$ & $-.666^{* *}$ & 1 & & \\
\hline OC & $-.468^{* *}$ & $0.362^{* *}$ & 1 & \\
\hline BD & $.393^{* *}$ & $-.403^{* *}$ & $-.322^{*}$ & 1 \\
\hline Bctinomycetes & -.233 & $.515^{* *}$ & .007 & .187 \\
\hline Fungi & $-.285^{*}$ & $.534^{* *}$ & .054 & 0.002 \\
\hline **. Correlation is significant at the $\mathbf{0 . 0 1}$ level (2-tailed). & $.399^{* *}$ & $-.630^{* *}$ \\
\hline *. Correlation is significant at the $\mathbf{0 . 0 5}$ level (2-tailed). & & \\
\hline
\end{tabular}

Devi et al., (2012) observed that fungal diversity had significant correlation with soil physico-chemical parameters and the altitude but its distribution showed negative correlation with altitude and soil moisture. The present findings with regard to fungal count along the elevation are contradictory to their report. Higher count (CFU) of microorganism as compared to our present estimates was reported by (Aurelia 2014) for bacteria $\left(34,68-36,8 \times 10^{6}\right)$, actinomycetes $\left(16,38-17,38 \times 10^{6}\right)$ and fungi $(1,29$ $\left.1,92 \times 10^{6}\right)$ in oak forest and pointed out that parameters such as acidity, $\mathrm{pH}$ values and moisture content and on the presence of organic matter, organic carbon and total nitrogen content in soil are the best predictors of bacterial and fungal community composition. Moreover, changes to the tree canopy naturally affect soil due to altered light and temperature conditions, and changes to the physical and chemical soil properties may influence the temporal and spatial heterogeneity of the microbial community. However, Zhan et al., (2013) reported that soil microbial communities and residues did not show any consistent altitudinal change along the elevation gradient at Changbai Mountain in China. Nevertheless, the higher fungal count in higher elevation of the forests in our study could be partially explained by vegetation types changing to coniferous forest as fungi are thought to be more efficient in the decomposition of recalcitrant phenolic compounds (Hackl et al., 2005) which have been identified with high quantities in coniferous forest (Gallet and Pellissier 1997). Lyngwi et al., (2013) in tropical forest of Eastern Himalaya reported that altitudinal gradient along with the vegetation and soil physico-chemical parameters were found to influence bacterial diversity and distribution where bacterial CFU showed positive but insignificant correlation with soil parameters like $\mathrm{pH}$, soil temperature, ambient temperature, soil carbon content, soil bulk density, soil urease and soil dehydrogenase. Altitude and soil moisture content showed negative correlation. Goldmann et al., (2015) reported that forest management types at more or less similar but geographically separated study sites induced a high level of distinctions in the composition of soil fungal communities. More disturbed sites, such as young beech forests and highly managed coniferous stands, were found to be composed of diverse fungal communities. Factors such as climatic variation, understory vegetation, root exudation profiles and rooting depths could contribute in shaping the fungal communities. Also, these fungi are prominent in soils rich in plant residues where competition for food and energy is not high but rapidly decline as the readily 
decomposable material decreases (Troeh 1993). Microbial population in the agricultural soil of Almora was reported by Maurya et al., (2011) where bacterial population was maximum followed by actinomycetes and fungal population. They further concluded that bacterial population increased with increase of the altitudes. In contrast to bacterial population, actinomycetal population decreased in the higher altitudes.

Among the studied soil properties, soil microflora such as fungi showed positive and significant correlation (Table 3) with soil organic carbon $(\mathrm{r}=0.399, \mathrm{p}<0.01)$. Interestingly, bacteria and actinomycetes did not show any relationship with organic carbon of the soil. All the microbes i.e. bacteria $(\mathrm{r}=$ $0.233)$, actinomycetes $\left(r=-0.285^{*}, p<0.05\right)$ and fungi $\left(\mathrm{r}=-0.450^{* *}, \mathrm{p}<0.01\right)$ were negatively correlated with $\mathrm{pH}$. However, EC had a positive relationship with bacteria $(\mathrm{r}=$ $\left.0.515^{* *}, \mathrm{p}<0.01\right)$, actinomycetes $(\mathrm{r}=$ $\left.0.534^{* *}, \mathrm{p}<0.01\right)$ and fungi $\left(\mathrm{r}=0.527^{* *}, \mathrm{p}<\right.$ $0.01)$. Similarly, negative relationship with soil bulk density was exhibited by fungi $(r=-$ $0.630^{* *}, \mathrm{p}<0.01$ ), while, actinomycetes and bacteria did not show any relations. Different section of microbes responds to varying edaphic factors and its environmental conditions. Our study found that soil microbes i.e. bacteria, fungi and actinomycetes showed significant positive relationship with soil organic carbon and electrical conductivity manifesting that organic material play an important source of food to microbial population as well as nutrient solubility in soil has good response in their growth and development. Similar results on fungal population in agriculture soils of Almora at high side on higher altitudes and maximum population of bacteria $\left(59 \times 10^{6} \mathrm{cfu} \mathrm{g}^{-1}\right.$ soil), fungi $\left(16 \times 10^{8} \mathrm{cfu} \mathrm{g}^{-1}\right.$ soil) and actinomycetes $\left(30 \times 10^{5} \mathrm{cfu} \mathrm{g}^{-1}\right.$ soil) at $6500-7000$ feet, 5500 6000 feet and 3000-3500 feet, respectively were observed by (Yadav, 2017).
In conclusion, soils from different $Q$ leucotrichophora forests types were found to harbour rich microbes as they provide congenial microclimate for its habitat and substrate requirements. Soil microorganisms respond very quickly to various natural and anthropogenic pressures or stresses acting on the soil ecosystem. Our study concluded that management of forest have a great influence in microbial population as seen in case of Reserved Forest (degree of protection is high) the counts of bacteria, actinomycetes and fungi were in the higher side while least was observed in Musterqua Forest (degree of protection is less). Moreover, higher count in Reserved Forest was supplemented by better soil physico-chemical properties. Bacterial and actinomycetes count showed decreasing trends with increasing elevation in all the forest types unlike fungi which increased with increasing elevation. The pattern of decreasing bacterial and actinomycetes count with elevation do corresponds to the results of many researchers for Himalayan forests whereas contradictory result of decreasing fungal count with increase in elevation was observed inviting detail analysis of such pattern.

Also, species wise identification needs to be done to explore beneficial microbes for recognizing their symbiotic association and to explore possibilities to harness and make use of beneficial microbes for forestry industrial application.

\section{Acknowledgments}

I would like to thank the officials of Rajgarh Forest Department for their kind support and also to the Department of Silviculture and Agroforestry (SAF) for providing us lab facilities to conduct our experiment. Further, I would like to acknowledge my parents and friends for their moral support and constant encouragement. 


\section{References}

Abbasi, M.K., Zafar, M., and Sultan, T. 2010. Changes in soil properties and microbial indices across various management sites in the Mountain Environments of Azad Jammu and Kahmir. Communications in Soil Science and Plant Analysis 41: 768-782.

Adams, P.W., and Sidle, R.C. 1987. Soil conditions in three recent landslides in southeast Alaska. ForestEcology and Management 18(2): 93-102.

Arunachalam, K., Arunachalam, A., Melkania, N. P. 1999. Influence of soil properties on microbial populations, activity and biomass in humid subtropical mountainous ecosystems of India. Biology and Fertility of Soils 30: 217-223.

Atlas, R.M. 1984. Diversity of microbial communities. In: Marshall KC (ed.) Advances in Microbial Ecology 7. Plenum press, New York.

Aurelia, O. 2014.Study of the correlations between soil physical, chemical properties and the number of microorganisms in oak forest soil. Analele Universităţii din Oradea, Fascicula Protecţia Mediului XXIII: 689-694.

Bardgett, R. D. 2005. The Biology of Soil: A community and ecosystem approach. Oxford.

Blank, R. R., and Fosberg, M. A. 1989.Cultivated and adjacent virgin soils in north central South Dakota: I. Chemical and Physical Comparisons. Soil Science Society of America Journal 53: 1484-1490.

Bryant, J. A., Lamana, C., Morlan, H., Kerkhoff, A. J., Enquist, B.J., and Green, J. L. 2008.Microbes on mountainsides: Contrasting elevational patterns of bacterial and plant diversity. PNAS105: 11505-11511.
Critter, S. A. M., Freitas, S.S., and Airoldi, C. 2002. Comparison between microorganism counting and a calorimetric method applied to tropical soils. Thermochimica Acta, 394: 133144.

De Hann, S. 1977. Humus, its formation, its relation with the mineral part of the soil and its significance for soil productivity In: Organic matter studies. International Atomic Energy Agency, Vienna pp. 2130.

De Jong, E., Schappeart, H. J. V., and Macdonald, K.B. 1974 Carbon dioxide evolution from virgin and cultivated soil as affected by management practices and climate. Canadian Journal of Soil Science 54: 299-307.

Devi LS, Khaund P, Nongkhlaw FMW and Joshi SR (2012) Diversity of culturable soil micro-fungi along altitudinal gradients of eastern Himalayas. The Korean Society of Mycology 40(3): 151158

Devi, N. L., and Singh, E. J. 2016. Soil respiration and microbial population in a subtropical mixed Oak forest of Manipur, North-eastern India. International Journal of Scientific and Research Publications 6 (7): 512-515

Edward, N.T.1975.Effect of temperature and moisture on carbon dioxide evolution in a mixed deciduous forest floor. In: Proc. Soil Science Society of America 39: 361-365.

Fierer, N., Mccain, C. M., Meir, P., Zimmermann, M., Rapp, J. M., Silman, M. R., and Knight, R. 2011. Microbes do not follow the elevational diversity patterns of plants and animals. Ecology 92(4): 797-804.

Fisher, R.F. 1995. Amelioration of degraded rain forest soils by plantations of native trees. Soil Science Society of America Journal 59: 544-549. 
Gairola, S., Sharma, C.M., Ghildiyal, S. K., and Suyal, S. 2012.Chemical properties of soils in relation to forest composition in moist temperate valley slopes of Garhwal Himalaya, India. Environmentalist: 1-12

Gallet, C., and Pellissier, F. 1997. Phenolic compounds in natural solutions of a coniferous forest. Journal of Chemical Ecology23: 2401-2412.

Giri, D.D., Shukla, P.N., Kashyap, S, Singh P, kashyap AK, Pandey, K. D. 2007.Variation in methanotrophic bacterial population along an altitude gradient at two slopes in tropical dry deciduous forest. Soil Biology and Biochemistry39: 2424-2426.

Goldmann, K., Schöning, I., Buscot, F., and Wubet T. (2015) Forest management type influences diversity and community composition of soil fungi across temperate forest ecosystems. Frontiers In Microbiology6:1-11.

Hackl E, Bachmann G, ZechmeisterBoltenstern S (2004) Microbial nitrogen turnover in soils under different types of natural forest. Forest Ecology \& Management 188: 101-112.

Hackl, E., Pfeffer, M., Donat, C., Bachmann, G., Zechmeister-Boltenstern, S. 2005. Composition of the microbial communities in the mineral soil under different types of natural forest. Soil Biology and Biochemistry37: 661-671.

Jackson, M. L. 1973. Soil chemical analysis. Prentic hall of India pvt ltd. New Delhi. 151-153.

Jalali, V. K., Talib, A.R., Takkar, P. N. 1989.Distribution of micronutrients in some benchmark soils of Kashmir at different altitudes. Journal of the Indian Society of Soil Science 37: 465-469.

Jina, B. S., Sah, P., Bhatt, M. D., Rawat, Y. S. 2008. Estimating carbon sequestration rates and total carbon stockpile in degraded and non-degraded sites of oak and pine forest of Kumaun Central Himalaya. Ecoprint 15: 75-81.

Jorgensen, J. R., Wells, C. G. 1973. The relationship of respiration in organic and mineral soil layers to soil chemical properties. Plant Soil 39: 373-387.

Kharkwal, G. 2002. Spatial pattern of plant species diversity with particular reference to forest herbs along an altitudinal transect in Central Himalaya. $\mathrm{PhD}$ Thesis, Kumaun University, Nainital, Uttarakhand, India.

Kumar, M., Sharma, C. M., Rajwar, G. S. 2004.A study on the community structure and diversity of a sub-tropical forest of Garhwal Himalayas. Indian Forester 130(2): 207-214.

Kumar, R., Kumar, R., Rawat, K. S., Yadav, B. 2012.Vertical distribution of physico-chemical properties under different topo-sequence in soils of Jharkhand.Journal of Agricultural physics 12(1): 63-69.

Laldinthar, R., and Dkhar, M. S. 2015.Relationship between Soil Bacterial Population and Various Physico-Chemical Properties at Two Broadleaved Forest Stands of Meghalaya Differing in Altitudes. Transcriptomics 3: 125.

Lauber, CL., Knight, R., Hamady, M., and Fierer, N. 2009. Soil $\mathrm{pH}$ as a predictor of soil bacterial community structure at the continental scale: a pyrosequencingbased assessment. Applied and Environmental Microbiology 75: 51115120.

Leifeld, J., Bassin, S., and Fuhrer, J. 2005.Carbon stock in Swiss agriculture soils predicted by land use soil characteristics and altitude. Agriculture, ecosystem and environment 105: 255266.

Lejon, DPH, Chaussod R., Ranger J., and Ranjard L. 2005. Microbial community structure and density under different 
tree species in an acid forest soil (Morvan, France). Microbial Ecology 50: 614-625.

Lyngwi, N.A., Koijam, K., Sharma, D.,and Joshi, S. R. 2013. Cultivable bacterial diversity along the altitudinal zonation and vegetation range of tropical Eastern Himalaya. Revista de Biología Tropical (International Journal of Tropical Biology and Conservation.) 61 (1): 467490.

Ma, X., Chen, T., Zhang, G., and Wang, R. 2004.Microbial community structure along an altitude gradient in three different localities. Folia Microbiologica 49: 105-111.

Margesin, R., Jud, M., Tscherko, D., and Schinner, F. 2009. Microbial communities and activities in alpine and subalpine soils. FEMS Microbiology Ecology67: 208-218.

Maurya, B. R., Singh, V., and Dhyani, P. P.2011.Enzymatic Activities and Microbial Population in Agric-soils of Almora District of Central Himalaya as Influenced by Altitudes.International Journal of Soil Science 6 (4): 238-248.

Meliani, A., Bensoltane, A., and Mederbel, K. 2012. Microbial diversity abundance in soil: related to plant and soil type. American Journal of Plant Nutrition and Fertilization Technology 2: 10-18.

Morisada, K., Ono, K., and Ramspott, B. L. 2004. Organic Carbon stock in forest soils in Japan. Geoderma 119: 21-32.

Murty, D., Kirschbaum, M. U. F., and McMurtrie, R. E. 2002. Does conversion of forest to agricultural land change soil carbon and nitrogen? A review of the literature. Global Change Biology 8: 105-123.

Naidu, R., McClure, S., and McKenzie, N. J. 1996. Soil solution composition and aggregate stability changes caused by long-term farming at four contrasting sites in South Australia. Australian Journal of Soil Research 34: 511-527.

Nair, P. K. R. 1984.Role of trees in soil productivity and conservation. Soil productivity aspects of agro-forestry. The International Council for Research in Agro-Forestry, Nairobi. 85pp.

Nsabimana, D., Haynes, R. J., and Wallis, F. M. 2004. Size, activity and catabolic diversity of the soil microbial biomass as affected by land use. Applied Soil Ecology26: 81-92.

Pandey, A., and Palni, L. M. S. 2007.The rhizosphere effect in trees of the Indian central Himalaya with special reference to altitude. Applied Ecology and Environmental Research 5(1): 93-102.

Pandey, A., Chowdary, V. M., and Mal, B. C. 2004.Morphological analysis and watershed management using GIS. Hydrology Journal of India 27(3-4): 7184.

Qin-S, J., LuDeGuo, Li-ZuoX., and Yu-Cui 2006. Preliminary study on dynamics of biological activity factors of forest rhizosphere. Journal of Jilin Agricultural University 28(3): 274-278

Ramesh, T., Manjaiah, K.M., Tomar, J. M., and Ngachan, S. V. 2013. Effect of multipurpose tree species on soil fertility and $\mathrm{CO} 2$ efflux under hilly ecosystems of Northeast India. Agroforestry Systems 87: 1377-1388

Reynolds, B., Neal, C., Hornung, M., Hughes, S., Stevens, P. A. 1988. Impact of afforestation on the soil solution chemistry of stagnopodzols in midWales. Water, Air, and Soil Pollution 38: 55-70.

Robertson, G. P., and Vitousek, P. M. 1981.Nitrification in primary and secondary succession. Ecology 62:376386.

Schinner, F., and Gstraunthaler, G. 1981. Adaptation of microbial activities to the 
environmental conditions in alpine soils. Oecologia 50: 113-116.

Semwal, S. 2006.Studies on phytosociology, diversity patterns and competition along an altitudinal gradient in a part of lesser Himalaya in Garhwal, Uttaranchal. D.Phil. Thesis, HNB Garhwal University, Srinagar (Garhwal), Uttarakhand, India.

Sharma, C. M., Gairola, S., Ghildiyal, S. K., and Suyal, S. 2010. Physical properties of soils in relation to forest composition in moist temperate valley slopes of the Central Western Himalaya. J. For. Sci. 26(2): 117-129.

Silva, D. K. A., Freitas, N. O., Sousa, R. G., Silva, F. S. B., Araújo, A. S. F., and Maia, L. C. 2012. Soil microbial biomass and activity under natural and regenerated forests and conventional sugarcane plantations in Brazil. Geoderma, 189: 257-261.

Singh, B. K., Bardgett, R.D., Smith, P., and Reay D.S. 2010. Microorganisms and climate change: Terrestrial feedbacks and mitigation options. Natural Review of Microbiology 8: 779-790.

Singh, B., Gill, R., and Gill, P. S. 2010.Soil fertility under various tree species and poplar-based Agroforestry system. Journal of Research Punjab Agricultural University 47: 160-64.

Snajdr J., Valaskova, V., Merhautova, V., Herinkova, J., Cajthaml, T., Baldrian, P. 2008. Spatial variability of enzyme activities and microbial biomass in the upper layers of Quercuspetraea forest soil. Soil Biology \& Biochemistry40: 2068-2075.

Srivastava, R.K., Khanduri, V. P., Sharma, C. M., and Kumar, P. 2005. Structure, diversity and regeneration potential of oak-dominant conifer mixed forest along an altitudinal gradient in Garhwal Himalaya. Indian Forester 131(12): 1537-1553.
Taboada, M. A., Lavado, R.S. 1993. Influence of cattle trampling on soil porosity under alternate dry and ponded conditions. Soil Use and Management 9:139-143.

Templer PH, Groffman PM, Flecker AS, Power AG (2005) Land use change and soil nutrient transformations in the Los Haitises region of the Dominican Republic. Soil Biology \& Biochemistry37: 215-225

Tornquista, C.G., Hons, F. M., Feagley, S. E., Haggar, J. 1999. Agroforestry system effects on soil characteristics of the Sarapiqui region of Costa Rica. Agriculture, Ecosystems and Environment 73: 19-28.

Troeh, F.R., Thompson, L. M. 1993. In: Soils and soil fertility (5th edition). Oxford University Press, New York

Usman, S., Singh, S. P., Rawat, Y. S., and Bargali, S. S. 2000. Fine root decomposition and nitrogen mineralisation patterns in Quercus leucotrichophora and Pinusroxburghii forests in Central Himalaya. Forest Ecology and Management 131:191-199.

Walkley, A., and Black, I. A. 1934. An examination of the Degtjareff method for determining organic carbon in soils: effect of variations in digestion condition and of inorganic soil constituents. Soil Science63: 251-263.

Wollum, A. G. 1982. Cultural methods for Soil Microorganisms. In: Methods of soil analysis. American Society of Agronomy Madison.781-813p.

Yadav, R. P. 2017. Land use appraisal along elevation gradient in Central Himalaya. $\mathrm{PhD}$ Thesis. Department of Silviculture and Agroforestry, Dr. YS. Parmar University of Horticulture and Forestry, Solan 403p.

Yang, C. K., and Yang, S. S. 2001.Microbial ecology of soils surrounding nuclear 
and thermal power plants in Taiwan. Environ. Intern. 26: 315-22.

Yao, M. K., Angui, P. K. T., Konate, S., Tondoh, J. E., Tano, Y., Abbadie, L., and Benest, D. 2010. Effects of Land use types on soil organic carbon and nitrogen dynamics in Mid-West Cote d'Ivoire. European Journal of Scientific Research 40(2): 211-222.

Young, A. 1991.Soil fertility. In: Avery ME et al., (eds.), Biophysical Research for Asian Agroforestry. Winrock International USA and South Asia Books, USA. pp.187-208.
Yousefifard, M., Khademi, H., Jalalian, A. 2007. Decline in soil quality as a result of land use change in Cheshmeh Ali region (IRAN). Journal of agricultural sciences and natural resources 14(1): 425-436.

Zhang, B., Liang, C., He, H., and Zang X. 2013. Variations in Soil Microbial Communities and Residues along an Altitude Gradient on the Northern Slope of Changbai Mountain, China. PLOS ONE 8(6): 66-184.

\section{How to cite this article:}

Pradeepen Rai, Bhupender Gupta, A.K. Gupta, Pempa Lamu Bhutia and Lalrintluangi Fanai. 2018. Effect of Management Regimes and Elevational Gradient on Soil Microbial Population of Quercus leucotrichophora A. Camus Forests in North-West Himalayas, India. Int.J.Curr.Microbiol.App.Sci. 7(09): 3205-3220. doi: https://doi.org/10.20546/ijcmas.2018.709.399 